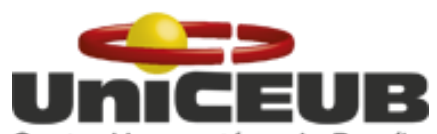 \\ Centro Unıversitárıo de Brasílıa \\ CENTRO UNIVERSITÁRIO DE BRASÍLIA - UNICEUB \\ PROGRAMA DE INICIAÇÃO CIENTÍFICA
}

RAQUEL BARROS DA SILVA

A CONTRIBUIÇÃO DO BHAGAVAD GITA PARA O ESTUDO DAS RELAÇÕES

INTERNACIONAIS: UMA INVESTIGAÇÃO A PARTIR DA CATEGORIA DE “AÇÃO

POLÍTICA AUTÔNOMA" (PURUSAKARA)

BRASÍLIA 
RAQUEL BARROS DA SILVA

\title{
A CONTRIBUIÇÃO DO BHAGAVAD GITA PARA O ESTUDO DAS RELAÇÕES INTERNACIONAIS: UMA INVESTIGAÇÃO A PARTIR DA CATEGORIA DE “AÇÃO POLÍTICA AUTÔNOMA" (PURUSAKARA)
}

\author{
Relatório final de pesquisa de Iniciação Científica \\ apresentado à Assessoria de Pós-Graduação e \\ Pesquisa.
}

Orientação: Prof. Dr. Raphael Spode 


\section{AGRADECIMENTOS}

Ao Programa de Iniciação Científica, pela bolsa ofertada e a confiança na pesquisa;

À minha família e amigos, pelo apoio e suporte;

Ao meu orientador Profo Raphael Spode, pela paciência e compreensão durante essa jornada pelo conhecimento. 
A mente funciona como um inimigo para aqueles que não a controlam

Bhagavad Gita 


\section{RESUMO}

A cátedra de Relações Internacionais busca compreender as dinâmicas da política mundial, nos mais diversos prismas teóricos existentes, com enfoque na supervalorização do primeiro grande debate, neste sentido refere-se a teoria realista e idealista. Entretanto, o campo de estudos das Relações Internacionais foi construída a partir da perspectiva norteamericana e eurocêntrica. A partir disso, as fontes de conhecimento pertencentes aos demais países passaram a ser marginalizadas. Nisso, a presente pesquisa pretende, avaliar a contribuição do Bhagavad Gita para os estudos das Relações Internacionais por intermédio de uma investigação sobre a categoria de ação política autônoma (purusakara) presente no texto indiano. Ademais, realizar uma análise comparativa da construção do conceito de autonomia política no oriente, em relação ao ocidente. Para isso, busca apresentar o pensamento dos autores brasileiros, como Amado Cervo e Sombra Saraiva, uma vez que ambos foram fundamentais na elaboração do conceito clássico. Todavia, trazer para essa reflexão o pensamento do Luciano Munõz, para evidenciar a inflexibilidade do conceito exposto pelo ocidente, visto que no sistema internacional há distintos comportamentos estatais. Apesar da desconstrução proposta por Luciano Muñoz, ainda existe o questionamento sobre o estabelecimento do pensamento não-ocidental, nesse caso a inserção do pensamento indiano. À vista disso, propor a inserção e a visibilidade do Bhagavad Gita, em comparação às bibliografias ocidentais do campo das Relações Internacionais, pois ainda permanece escasso a abertura para os conceitos orientais, resultando na perda significativa do debate teórico, uma vez que a inserção de textos nãoocidentais, principalmente o conhecimento indiano, resultaria no enriquecimento da discussão.

Palavras-chaves: Bhagavad Gita. Autonomia Política. Relações Internacionais. 


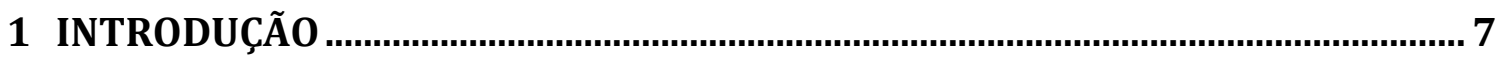

1.1 OBJETIVOS

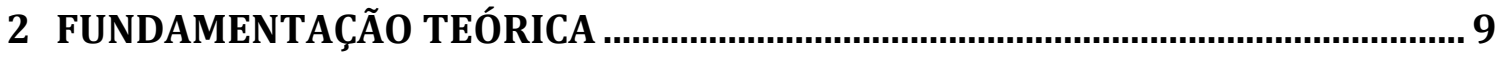

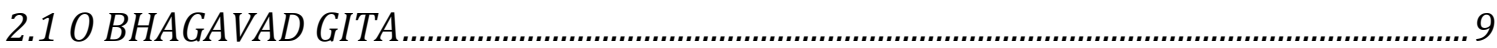

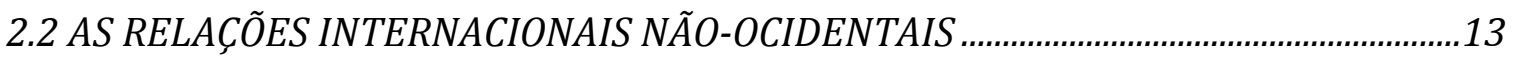

3 METODOLOGIA

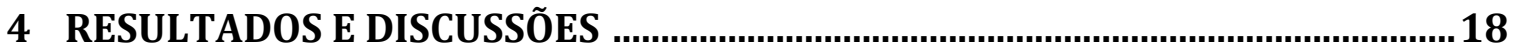

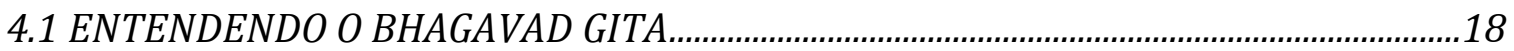

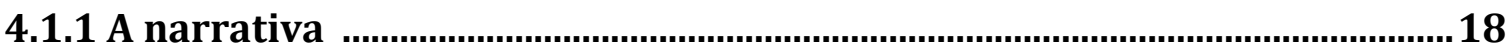

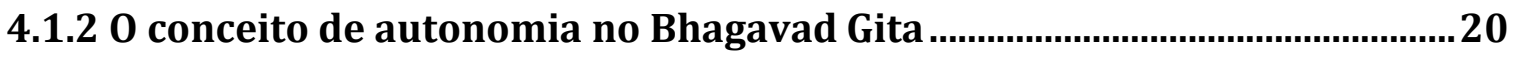

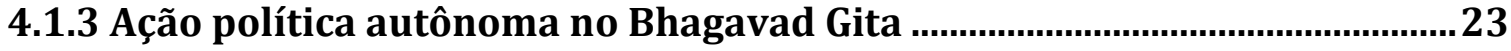

4.2 O CONCEITO DE AUTONOMIA NA PERSPECTIVA OCIDENTAL ....................................32

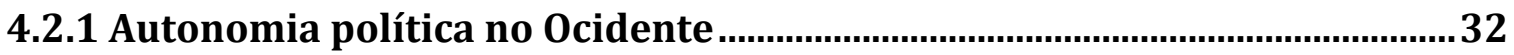

4.2.2 Autonomia Ocidental versus autonomia no Bhagavad Gita .........................33

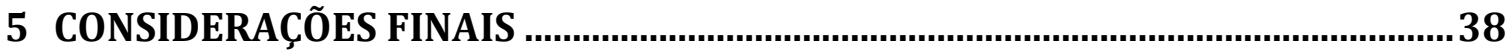

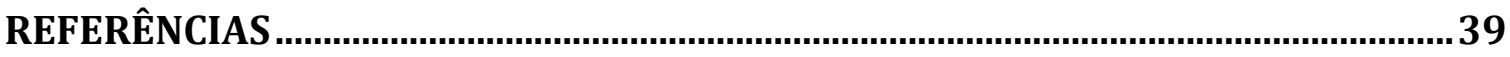




\section{INTRODUÇÃO}

O Bhagavad Gita é um texto clássico na cultura indiana, principalmente para a religião hinduísta, pois narra o dilema do príncipe Arjuna, na guerra familiar entre Pandavas e Kauravas. A grande diferença para os demais textos sobre líderes políticos e conflitos, é a presença de Krishna, um dos avatares do deus Vishnu, que passa a aconselhar Arjuna. Dessa forma, a obra apresenta sua faceta política, mas entrelaçado com o aspecto religioso.

Notamos que a cátedra de Relações Internacionais foi construída a partir da visão europeia e norte-americana, e os demais países foram esquecidos nessa trajetória. Diante disso, surge a reivindicação dos teóricos não-ocidentais, em busca de novos espaços para esses continentes que foram marginalizados, poderem ter a mesma visibilidade, no molde atual que as Relações Internacionais se apresenta.

No entanto, para construção de uma disciplina que possa abranger tanto o ocidente quanto o oriente, é necessário a contribuição textual de todos os continentes, um dos textos que poderá contribuir conceitualmente para o campo das Relações Internacionais é o Bhagavad Gita, por ser um texto que aborda diversas temáticas fundamentais para o campo de estudos.

Assim, buscamos compreender como a cultura indiana pode contribuir na construção do conceito de autonomia política nas Relações Internacionais. Sendo assim, o que vamos apresentar neste trabalho é a contribuição do Bhagavad Gita para os estudos das Relações Internacionais, através da reflexão do conceito de ação política autônoma, baseada na visão indiana.

Posto isto, na primeira seção será importante entender o Bhagavad Gita, em relação a sua narrativa e como é expresso na obra, o conceito de autonomia e ação política autônoma. Para que na segunda seção, seja possível realizar uma análise comparativa entre o conceito de autonomia política no oriente, em relação ao ocidente, com a contribuição do Amado Cervo e Sombra Saraiva, dois autores clássicos do ocidente, e as críticas da construção clássica do conceito com a perspectiva de Luciano Muñoz. E consequentemente, abrir a discussão se na desconstrução do pensamento clássico ocidental, surgiu a preocupação na inclusão teórica do oriental. 
Ao analisarmos a cultura indiana, notamos que os textos sagrados podem ser usados como uma fonte de conceito inserido no campo das Relações Internacionais, com a mesma valorização das obras utilizadas nas teorias clássicas do campo, com enfoque no texto de Hans Morgenthau, para a teoria realista. Dessa maneira, ser possível a abertura da cátedra para se globalizar teoricamente.

\subsection{OBJETIVOS}

O objetivo geral da pesquisa foi avaliar a contribuição do Bhagavad Gita para os estudos das Relações Internacionais por intermédio de uma investigação sobre a categoria de ação política autônoma (purusakara) presente no texto indiano. Além disso, também se teve como objetivo:

a) Estudar o Bhagavad Gita e refletir sobre sua contribuição para os estudos das Relações Internacionais;

b) Investigar a categoria de ação política autônoma (purusakara) presente na narrativa indiana;

c) Realizar a releitura e o resgate de textos tradicionais em Relações Internacionais;

d) Sustentar uma abordagem conceitual que leve em consideração diferentes religiões, culturas e civilizações da sociedade mundial;

e) Diminuir o ocultamento de outras realidades culturais;

f) Promover a ética da alteridade e os esforços de reconhecimento do 'outro' em seus próprios termos culturais;

g) Encontrar novos espaços semânticos e novas possibilidades de relação com as diferentes realidades do mundo;

h) Apresentar alternativas conceituais e uma heurística diferenciada capaz de servir como crítica à teoria de Relações Internacionais;

i) Contribuir para a diversificação teórica da área. 


\section{FUNDAMENTAÇÃO TEÓRICA}

\subsection{O BHAGAVAD GITA}

PRASÃD, Rãmãnanda. O Bhagavad Gita: A canção de Deus. Trad. Sri Swãmi Krsnapryãnanda Saraswãti. 2. ed. Porto Alegre: Sociedade Internacional do Gita do Brasil, 2005.

O texto cita que o Estado detém o uso da força, no entanto dizer que fazer o mínimo de uso dela é subjetivo, porém a violência só poderá ser aplicada para manter o dharma (ordem ou justiça), em nenhuma hipótese poderá ser usada para resolver problemas de rancor pessoal. (BHAGAVAD GITA, 2005).

“O dever do ksatriya (rei) é proteger os cidadãos de toda classe de dificuldades, e
por esta razão ele tem que aplicar a violência em casos apropriados para manter
a lei e a ordem. Portanto, ele tem que conquistar os soldados dos reis inimigos, e
assim, com os 'princípios religiosos', ele deve governar o mundo" (BHAGAVAD
GITA, 2005, p. 77).

Os três condutores para uma ação que são o sujeito, o objeto e o conhecimento. Quando o indivíduo enxerga o conhecimento sendo algo indivisível e imutável em todos os seres vivos, o mesmo se encontra na perspectiva da bondade, diferente de quando o conhecimento de alguém enxerga cada ser diferente um do outro, esse está na visão da paixão, e por último o irracional que só se baseia em uma característica, como o corpo ou beleza, tendo isso como o mais importante, esse tipo de conhecimento é entendido como ignorância.

Há três tipos de ação, a primeira está relacionada com a bondade, ou seja, quando o indivíduo precisa exercer determinadas ações mesmo não gostando, sem visar recompensas e sem nenhum tipo de egoísmo; já a segunda são aquelas que são motivadas por interesses próprios e egoístas, está se enquadra na paixão; e a terceira baseia-se nas ações tomadas pelas questões ilusórias, sem ponderar as consequências e os danos que podem gerar tanto para si, quanto para o próximo, esse tipo está no modo da ignorância. “O Senhor onipotente não assume nem a má nem a boa ação de ninguém. Mas a ausência de conhecimento, que recobre o conhecimento, é por ela que os homens se desorientam" (BHAGAVAD GITA, 2005, p. 15).

As três formas de agir, o primeiro é o não agir trata-se da inatividade e omissão, é um agir perverso e negativo, uma vez que está ligado com a ociosidade; o falso agir é o negativo que agride tanto os outros seres humanos quanto a própria natureza; o reto agir não é de fácil distinção, pois é a observância de todos os 
mandamentos e leis, da liberdade, do respeito, da responsabilidade do amor, e um dos princípios mais importantes, é o desapego (BHAGAVAD GITA, 2005, p.17).

O texto aborda também os três tipos de agentes, a pessoa que não é egoísta e que faz tudo com bom ânimo e não se deixa abalar pelos acontecimentos tanto bons quanto os ruins, é visto como bom; os indivíduos que são impacientes e violentos, que sempre almeja as recompensas do trabalho e sempre se abala com as adversidades, e denominado como apaixonado; as pessoas ignorantes são os indisciplinados, teimosos, maliciosos, preguiçosos e procrastinadores.

A divisão do intelecto é baseada na natureza material, o intelecto daqueles que consegue diferenciar de forma clara as dicotomias da ação, estão no modo da bondade; quando o intelecto está na perspectiva da paixão, o indivíduo não consegue separar o reto agir (dharma) e ação contrária ao dever (adharma), e a ação correta e errada; quando a pessoa ignora as injustiças (adharma) e aceita como se fosse justiça (dharma), está no modo da ignorância.

Segundo Bhagavad Gita (2005), cada indivíduo possui seu karma e dharma, sendo que o karma é a justiça e a lei eterna, já o dharma é o dever de casa pessoa, a retidão e virtude. Com isso, o karma é criado pelos pensamentos, palavras e atos de cada indivíduo, sem suas experiências anteriores, porém ele vai constituir o dharma atual. A moralidade está intimamente ligada com o dever (dharma), uma vez que é algo individual e se baseia no dharma e não na noção "do bem e mal absoluto".

\footnotetext{
Nascer numa situação de constante guerra feudal era o karma de Arjuna. Mas esse nascimento fez com que se lhe tornasse possível executar um dharma particular, com um importante fator de vitória do caminho aberto da consciência e da atividade que foi também o caminho da individualização espiritual. Era o processo oferecido para tornar-se um indivíduo autônomo, autoconfiante e responsável, nos termos que a Índia, como um todo necessitava naquele momento (BHAGAVAD GITA, 2005, p. 42).
}

Em relação às castas que a sociedade indiana possui, o texto cita que todos nascem iguais, porém o que define a superioridade ou inferioridade são as suas próprias ações.

Estas quatro ordens sociais universais da sociedade humana são descritas pelo Senhor Krsna relacionando a natureza pessoal de cada um, qualidades, trabalhos, e não o seu nascimento. Aqueles que estão dominados pelo modo de bondade e são pacíficos, e autocontrolados, são chamados de Brãhmanas. Aqueles que são controlados pela paixão e preferem engajar-se na administração e serviços de proteção são classificados como Ksãtriyas. Aqueles sobre os modos mistos de paixão e de ignorância e que engajam-se na agricultura e no comércio, são chamados de Vai yas. Aquela maioria, que se encontra no modo inferior ou da ignorância, são chamados de Sudras, e suas naturezas são de servir a outras três ordens sociais (BHAGAVAD GITA, 2005, p. 323). 
TURCI JÚNIOR, José Rubens. Uma visão polifônica sobre a gênese da ciência do sagrado no Bhagavad Gita. Revista de estudos e pesquisa da religião, Juiz de Fora, v. 14, n. 2, p. 247260, set. 2011.

O autor cita que o Bhagavad Gita relata a guerra entre os Kauravas e Pandavas pela disputa de poder, porém ambos os clãs possuem o mesmo peso na descrição dos relatos. Diante disso, temos uma nova interpretação do sagrado, há também a possibilidade de entendermos os fundamentos da atividade humana e da filosofia da ação.

Krșna discorre na Gïtā sobre os dois aspectos da ação humana, entendidos até
então como mutuamente exclusivos: pravrtti (movimento de exteriorização, ou
de ação concreta na realidade objetiva) e nivrtti (subjetivo; movimento de
interiorização - ou de "não-ação" -, decorrente do entendimento e controle de
todo o processo de formação da vontade). Pravrtti e nivrtti comporiam, desta
forma, os dois eixos do processo gradual de síntese dialética da atividade humana
(TURCI JÚNIOR, 2011, p. 249).

No texto notamos que a organização psicológica do indivíduo é composto em torno das suas próprias faculdades de cognição, vontade, ação e síntese. Além disso, observamos que a razão pura controlam o lado emocional, sendo que o mesmo controlam as faculdades de cognição, vontade, ação e síntese, e com todos esses fatores equilibrados contribui para atingirmos o nirvana.

O processo de síntese dialética entre pravrtti e nivrtti presente na Gïtopadeśa
ilustra, por exemplo, a filosofia da ação política de Gandhi, fundada em torno dos
conceitos de sātyagragha (o vigor do amor e da verdade em ação) e sarvodaya
(crescimento e bem-estar de todos). A base epistemológica da filosofia da ação
política de Gandhi, bem como a sua heurística, somente podem ser
compreendidas através deste entendimento sintético exposto na Gitāa sobre como
se dá o controle de todo o processo de formação da vontade. Perpassando a sua
prática está a ética dialética definida no diálogo entre Krșna e Arjuna, que será
delimitada a seguir em termos bakhtinianos (TURCI JÚNIOR, 2011, p. 251).

Nesse sentido, para Gandhi ação política está intimamente ligada com a com o domínio sobre o processo da formação de vontade, uma vez que os pensamentos, afetos e percepções afetam as tomadas de decisão das políticas públicas, tanto sociais quanto as de cidadania. O autor cita que sraddhã significa "considerar racionalmente (dhã) sob a sagrada luz do coração (srat)" (TURCI JÚNIOR, 2011, p. 252), expressando assim o domínio e o controle, em relação ao processo de formação da vontade.

Para Turci Júnior, o Gita expressa a consciência dentro do Mahãbhãrata, uma vez que "o espaço da consciência universal, presente no coração de cada indivíduo, onde a ação é refletida, tornando-se substância para a filosofia moral" (TURCI JÚNIOR, 2011, p. 254). 
O texto cita que a razão e a sensibilidade mostrada no Gita, faz com que passamos a entender o indivíduo e a sua experiência, além do dharma individual, no entanto, surge a partir do sraddhã, fazendo com que a ação humana não necessite de álibi (postupok), visando assim a emancipação do ser humano.

\begin{abstract}
Aquilo que deve ser entendido como dever sagrado na Gïtā está em consonância com a noção de dever (dolzhenstvovanie) em Bakhtin e com aquilo que representa a sua filosofia da ação. Tal como no pensamento de Bakhtin, a Gītā associa o valor moral da ação não com a ação em si mesma, mas com a sua motivação. É esta dimensão revolucionária da consciência que possibilita, em dados momentos, a ruptura com os valores da tradição (TURCI JÚNIOR, 2011, p. 257).
\end{abstract}

FREIBERGER, Mário J. A dimensão da Ação e Tempo. In: FREIBERGER, Mário J. Ação e tempo na Bhagavad- Gita. Porto Alegre: EDIPUCRS, 1996. p. 46-47.

A dimensão da Ação e Tempo. In: FREIBERGER, Mário J. Ação e tempo na Bhagavad- Gita. Porto Alegre: EDIPUCRS, 1996. p. 52-55.

A dimensão da Ação e Tempo. In: FREIBERGER, Mário J. Ação e tempo na Bhagavad- Gita. Porto Alegre: EDIPUCRS, 1996. p. 62-63.

\title{
1. Auto-escolha
}

No Bhagavad- Gita, o conceito de autonomia é abordada de uma maneira particular, pois está diretamente relacionado com a ideia de karman. Todos os seres humanos possuem o direito de fazer escolhas, porém essas escolhas são autoconscientes. Até o ato de negar-se a tomar decisões é válida, no entanto faz com que o indivíduo perca parte da sua humanidade, ou seja, a mesma torna-se submissa das demais pessoas que terão que fazer essas escolhas, mesmo os que se abdicaram de fazerem suas próprias escolhas, terão o karman proveniente da omissão.

A ação está relacionada com a subjetividade, devido a isso as ações podem ser modificadas ao decorrer do tempo. Porém, vale ressaltar que o tempo ocupa um espaço, a partir do momento que coexiste o sujeito temporal e as ações tomadas em um determinado contexto (FREIBERGER, 1996, p. 46).

\section{Ação temporal}

De acordo com Bhagavad- Gita, a ação temporal é manifestada por meio do karman, que conduz o tempo- história. O karman é o resultado das ações realizadas pelos indivíduos mais as consequências dos seus atos, ou seja, toda a ordem do mundo é um reflexo das escolhas humanas, levando cada indivíduo a se responsabilizar por suas escolhas. 
O conceito do karman também se aplica no âmbito das relações internacionais, como representado no dilema de Arjuna. "Na esfera das relações internacionais, a lei do karman manifesta-se em termos de adequação do poder e da justiça. (...) Visto sob o aspecto da violação e da ação, o universo, como uma ordem ética inviolável. Nisso reside o significado específico da lei do karman" (HANSON; STERWART, 1985 apud FREIBERGER, 1996, p. 49).

A lei da ação equilibrada constitui a última fase da ciência e da religião, a mesma é responsável por preservar a totalmente energia, ou seja, a pedra angular da ciência, em contraposição assegura todos os princípios morais, que corresponde toda a base da ética e religião.

\section{Dois lados da mesma face}

Enquanto o karman está relacionado com a ação, fazendo com que todas as ações sejam problematizadas, já o dharma corresponde ao dever de cada pessoa. Diante disso, a noção de ações boas ou más será relativa, pois o julgamento vai ser baseado no dharma individual.

\section{O efeito da sobrevivência da ação}

Em suma, a ideia de imortalidade da alma é um processo contínuo e infinito, que colabora para o aperfeiçoamento moral. No entanto reflete na autonomia decisória de todos, pois influencia tanto na postura mental da sociedade civil, quanto nas tomadas de decisão do Estado soberano.

\subsection{AS RELAÇÕES INTERNACIONAIS NÃO- OCIDENTAIS}

ACHARYA, Amitav. Dialogue and discovery: in search of International Relations Theories beyond the west. Millennium: Journal of International Studies, United Kingdom, v. 39, n. 3, p. 619 - 637, out. 2011.

\section{Questões de contenção}

As três questões principais para avançar os estudos de Relações Internacionais, a primeira questiona se as teorias existentes, já são suficientes para explicar tanto o lado ocidental, quanto o oriental; O segundo questionamento é se as teorias indianas acabaram 
são cópias das teorias ocidentais; e por fim, se devemos envolver escolas de pensamento nacionais ou regionais, na construção das teorias de Relações Internacionais.

Segundo Acharya, o oriente não pode descartar teorias ocidentais, por serem irrelevantes para os seus atores, também se aplica para o ocidente, pois isso seria uma armadilha relativista. Entretanto, há expressivas lacunas nas relações políticas, econômicas e de segurança por parte não ocidental.

De acordo com Olson e Onuf, o campo de Relações Internacionais deveria ser um espaço cosmopolita, uma vez que enriqueceria um debate acadêmico, porém essa globalização de ideias poderia indicar a exitosa difusão intelectual anglo-americano, em vez da abertura indiana no pensamento ocidental.

As escolas de pensamento acrescenta no debate, a partir do momento que não venham carregadas de nacionalismo e paroquialismo excessivo, pois Acharya afirma que a maioria delas são internamente homogêneas ou extremamente exclusivas. Por outro lado, as mesmas podem tomar um rumo extraordinário, criando barreiras à pluralização e a discursos transnacionais e regionais.

As Relações Internacionais da Índia busca com que os estudantes da área contribua para o aumento de conhecimento sobre o papel da Índia como um poder responsável pela promoção da paz, segurança, economia. Porém, não significa a criação de uma escola indiana de Relações Internacionais, mas para construir uma visão das RI indiana e verídica, pois a partir do momento que o pensamento indiano criado fora da índia, fez com que caísse em um nativismo ou uma busca de visão "indiana" essencialista.

\section{Genealogia de Sistemas Internacionais}

As teorias de Relações Internacionais, não possui fonte ocidental, mas também do Mediterrâneo Clássico. "We are yet to see such grand theorising from the Sumerian, Egyptian, Chinese or Indian pasts, stuck as we are with the idea of Kautilya being an Indian Machiavelli, rather than Machiavelli being a Euro-Mediterranean Kautilya" (ACHARYA, 2011, p. 628).

\section{Agência}

A genealogia está diretamente ligada com a agência, ou seja, quando a noção de padrões de civilização substitui as leis naturais, que reconheceu o status de todas as nações 
a luz do direito internacional, negou a agência de políticas e sociedades não ocidentais nos assuntos internacionais.

The Latin American and African norms of inviolability of post-colonial boundaries, Latin America's strengthening and institutionalisation of non-intervention, norms of Arabism from the Middle East, and the Asian construction and modification of the non-intervention norm to delegitimize great power alliances and power balancing are some examples of such normative agency. Although some of these norms are of Western origin, their creative adaptation and repatriation are important examples of agency that cannot be denied a place in IR theory (ACHARYA, 2011, p. 629)

\section{Humanizando as Teorias de Relações Internacionais}

A partir do momento que coloca o indivíduo no centro do debate de Relações Internacionais, é de suma importância, porém os conceitos pré-fixados pelo homem, embora atraiam crescente interesse, não foi avançado ao ponto em que eles desafiam a centralidade do Estado, ou a Instituições Internacionais controladas por Estados, em qualquer uma das teorias ocidentais.

\section{Trazendo estudos de área de volta}

O Oeste tinha sido tradicionalmente ancorado, em uma época em que o mesmo e possuía uma necessidade constante de trazer de volta os estudos de área, e quando a concepção tradicional de estudos da área está mudando, especialmente com o advento do que pode ser chamados "estudos transnacionais", por estudiosos que têm interesse nos assuntos regionais, e cada vez mais interessados e envolvidos em pesquisas comparativas sobre fenômenos trans-regionais, com ou sem a ajuda da teoria de uma determinada disciplina.

\section{Mundos regionais contemporâneos}

O discurso teórico modifica-se em cada região, porém cada um acrescenta no debate acadêmico, mas isso gera uma grande problemática na área, porque não é seguido na prática, já que uma parcela significante das teorias foi criada pela Europa, porém não são questionadas, enquanto as teorias asiáticas e africanas são marginalizadas.

\section{Como estudar RI: A questão da epistemologia}

Segundo Jackson, o conhecimento científico precisa ser sistemático, capacidade em abordar a crítica pública e produzir conhecimento mundano, porém nos países não- 
ocidentais, essa estrutura de conhecimento é válida, já que as fontes podem ser a religião e conhecimento cultural, ou seja, pode estar entre a ciência e espiritualidade ou a combinação do material e espiritual.

In other words, Lord Krishna's pleadings with the warrior Arjuna not to abstain from war resonate with the logic of righteous action which is both 'this-worldly' (honour, shame, power) and 'other-worldly' (the indestructibility of the soul or the atman).

Can we bring these insights into IR knowledge if we insist on a conduct of enquiry that demands a strict separation between this- and other-worldliness, and between the material and the spiritual? We could of course self-consciously include elements such as scriptural knowledge which may not easily pass the test of this-worldliness, and call them the non-scientific elements of IRT (ACHARYA, 2011, p. 634).

O mesmo ainda afirma que a insistir em um padrão ocidental para validar as fontes ditas como "corretas", acabam marginalizando fontes de conhecimento de RI que são totalmente ou parcialmente não científica, ou cuja afinidade não pode ser claramente estabelecida com a ciência.

\section{Conclusão}

Um dos principais desafios enfrentados pelas Rl, é o fracasso em entender e promover um desenvolvimento como um diálogo de mão dupla, pois as estruturas de poder, determinados pensamentos baseados na história e pela identidade, impedem o reconhecimento da agência e da contribuição de outras vozes, mesmo sabendo da sua existência.

Para Acharya e Sen, rejeitam a ideia de que a tradição cabe a um determinado país do oriente, mas depois cabe ao ocidente decidir se vai aceitar ou não a fonte, em vez de reconhecer todas as fontes como herança global, como o Bhagavad- Gita.

Entretanto, as teorias de Relações Internacionais estão sempre ligadas a herança ocidental, apenas o momento que descobrimos as suposições e estruturas de poder que impedem as teorias serem herança global, serão encerradas as divergências, para abrirmos espaço para o diálogo e descobertas. 


\section{METODOLOGIA}

A presente pesquisa apresentou o estudo qualitativo do tema: A contribuição do Bhagavad Gita para o estudo das Relações Internacionais: uma investigação a partir da categoria de "ação política autônoma" (purusakara), mais precisamente sobre a problemática.

Para de forma específica analisar o presente tema, a pesquisa se deteve na seguinte metodologia:

- Natureza: enquadrou-se em pesquisa básica, analisando a obra do Bhagavad Gita;

- Quanto a forma de abordagem do problema: teve abordagem qualitativa, uma vez que os resultados da pesquisa foram obtidos através da análise da obra clássica indiana;

- Quanto ao tipo: a pesquisa se aplica na descritiva, pois a partir da análise do Bhagavad Gita, identificamos o conceito de autonomia, para contribuição no pensamento teórico de Relações Internacionais;

- Quanto aos procedimentos técnicos: a pesquisa foi bibliográfica, por possuir embasamento no texto do Bhagavad Gita, além dos artigos comentando sobre a obra. 


\section{RESULTADOS E DISCUSSÕES}

\subsection{ENTENDENDO O BHAGAVAD GITA}

A presente seção apresentará o texto sagrado intitulado Bhagavad Gita. Com intuito de, retratar o conceito de autonomia em um panorama geral, e por fim a construção do pensamento indiano acerca da ação política autônoma (purusakara). Ao analisar a obra, notamos que o conceito de autonomia política possui uma definição específica, posto que o mesmo estabelece um diálogo entre as ações humanas e o transcendental.

\subsubsection{A narrativa}

O Bhagavad Gita é um texto sagrado hindu datado do século IV a.C. Trata-se de um episódio da epopeia denominada Mahabharata. Dividindo espaço com o Ramayana, o Mahabharata é considerado uma expressão nuclear do 'sagrado' na Índia. Sendo um dos textos mais cultuados pela espiritualidade indiana, o Mahabharata é um clássico: apreciado há mais de 2.000 anos, a epopeia pode ser entendida como um verdadeiro apanhado sobre a dimensão espiritual e psicológica da humanidade (ELIADE, 2011, p. 207; FREIBERGER, 1996, p. 13-26).

O Mahabharata está dividido em dezoito livros e cada livro apresenta diversas histórias. Essas histórias narram o conflito entre os cem descendentes de Kuru (denominados Kauravas) e os cincos descendentes de Pandu chamados Pandavas. Dentro de um universo antológico de alta complexidade, o Bhagavad Gita se apresenta como uma história singular da conflituosa relação entre Kauravas e Pandavas, ou seja, se trata de uma parte apenas do Mahabharata, uma cena, para ser mais específico, de uma história mais longa. Os eixos centrais do Bhagavad Gita são a descrição da manifestação do deus Vishnu no avatar Krishna e a narrativa da guerra entre Kauravas e Pandavas (ELIADE, 2011, p. 207-208).

O enredo que sustenta o diálogo entre Arjuna e Krishna é a guerra entre Kauravas e Pandavas. Conta-se que essa guerra foi a consequência drástica de uma disputa entre parentes e remonta a tormentosa relação entre os irmãos Dhritarâshtra e Pându. Essa história inicia em tempos remotos, quando reinava em Hastinapura o rei Vichitraviría. Casado com duas irmãs, o rei faleceu sem deixar descendentes. Conforme a tradição do 
povo, o irmão do falecido rei, Vyâsa tomou as viúvas por consortes e teve dois filhos com elas, na seguinte ordem: Dhritarâshtra e Pându. Dhritarâshtra, o mais velho, teve cem filhos, sendo seu primogênito Duryôdhana. Pându, o filho mais moço, teve cinco filhos, todos conhecidos pelas suas virtudes, os Pandavas (LORENZ, 2006, p. 7-13).

Com a morte de Vyâsa, o trono deveria ser herdado pelo primogênito, ou seja, Dhritarâshtra. Esse, porém, era cego e de acordo com a tradição do rei guerreiro e protetor viril (uma tradição denominada "xátria", que presumia que o rei deveria ser um homem em plena posse de suas faculdades física e morais) considerado inapto ou inelegível ao trono. Desse modo, Pandu assumiu o trono como o único herdeiro viável. Porém, com a morte prematura de Pandu, Dhritarâshtra assumiu o trono como suplente até que o herdeiro e primogênito de Pandu, Yudhishthira tivesse idade suficiente para assumir o poder de direito e fato. Quando Yudhishthira atingiu a idade mínima para governar, Dhritarâshtra se negou a passar o trono à dinastia de seu irmão, confabulando com seus filhos e em especial Duryôdhana, o seu primogênito uma trapaça que tirou dos Pandavas o direito de governar e condenou-os a um exílio de treze anos (ELIADE, 2011, p. 207-208).

No ostracismo, os Pandavas passaram por diversas dificuldades. Depois de contratempos e jornadas heróicas - descritas em outras passagens do Mahabharata - os irmãos voltaram para reaver o seu legado, com o apoio de vários líderes dos reinos e tribos da região. Entre estes líderes se encontra Krishna, figura central do Gita. Apesar de ser a encarnação do deus Vishnu, sua forma é humana: ele figura ser um príncipe de um reino simpático a causa dos Pandavas que, desejoso a ajudá-los na guerra justa contra o exército de Dhritarâshtra, se voluntaria para ser o guia da carruagem e conselheiro de Arjuna, o terceiro Pandava de uma linhagem de cinco filhos (FEUERSTEIN, 2015, p. 121).

O Bhagavad Gita inicia justamente com a descrição do cenário que antecede o início da guerra. Quem faz a descrição deste cenário de guerra é Samjaya, o conselheiro político do rei dos Kurus, Dhritarâshtra. Instalado em sua tenda real, às proximidades dos acontecimentos, o rei escuta Samjaya. Cego, Dhritarâshtra não pode ver os batalhões, nem o que está acontecendo. Por essa razão, Samjaya procura atenuar sua ansiedade e faz isso através da transmissão oral dos acontecimentos, descrevendo os últimos ajustes dos comandantes, o estado emocional dos soldados e o aspecto das forças do inimigo (LORENZ, 2006, p. 25-27; FEUERSTEIN, 2015, p. 79-85). 
Após a narrativa de Samjaya à Dhritarâshtra, o Gita volta-se a figura de Arjuna, o príncipe Pandava: ele está paralisado, em pleno campo de batalha, por uma inquietação moral. O príncipe percebe, num relance de consciência, que está lutando contra parentes. Ao ver o rosto de tios e primos queridos de outrora, sente-se sem forças. Sob um terrível conflito interior, sua missão e dever político como xátria corre risco. Sentindo o peso das circunstâncias, Arjuna baixa seu arco e, em estado de crise, pensa desistir da batalha. Nesse instante, Krishna questiona seu dilema e procura ajudá-lo a encontrar uma solução. É então que a história encaminha uma revelação espiritual problematizando as motivações humanas, os entraves políticos e sociais, a natureza da responsabilidade e da ação humana, as noções de certo e errado, justo e injusto, e as verdades e ilusões provocadas pelo mundo material (ou imediato) sobre os sentidos (FEUERSTEIN, 2015, p. 79-91; LORENZ, 2006, p. 1524; PRABHUPADA, 1985, p. 1-18).

\subsubsection{O conceito de autonomia no Bhagavad Gita}

No Bhagavad Gita a ideia de karman, dharma e autonomia são coexistentes, ou seja, o conceito de autonomia não pode ser desvinculado a noção do karman. Porém, primeiramente é necessário compreendermos como cada conceito citados anteriormente são expressos na obra, já que constituem toda a base da formação do pensamento de autonomia na perspectiva indiana. Para Freiberg (1966), o sentido de dharma seria o dever de cada pessoa no plano terrestre, nesse cenário a concepção das ações positivas e negativas são relativas, pois o julgamento vai acontecer a partir do dharma individual. Em vista disso, o conceito de dharma no Bhagavad Gita é definido como "princípios religiosos; a ocupação eterna e natural do ser (i.e., serviço devocional ao Senhor)" (PRABHUPADA, 1985, p. 864).

Em contrapartida, Freiberg (1966) cita que o karman é associado com ações praticadas mais as consequências dos atos de cada indivíduo, pois toda ordem do mundo é uma reverberação das escolhas humanas, assim faz com que todos os indivíduos sejam responsabilizados pelas suas próprias tomadas de decisões. "A ação que desencadeia o desenvolvimento dos corpos materiais das entidades vivas chama-se karman, ou atividades fruitivas" (PRABHUPADA, 1985, p. 424), ou seja, são as "atividades materiais mediante as quais a pessoa incorre em subsequentes reações" (PRABHUPADA, 1985, p. 865). 
Nesse sentido, é possível notarmos a aplicação dos conceitos de karman e dharma na prática, observando o caso de Arjuna. O karman do príncipe era árduo e imutável, porém isso fez com que seu dharma fosse benéfico tanto para o príncipe quanto para a população indiana.

\begin{abstract}
Nascer numa situação de constante guerra feudal era o karman de Arjuna. Mas esse nascimento fez com que se lhe tornasse possível executar um dharma particular, com um importante fator de vitória do caminho aberto da consciência e da atividade que foi também o caminho da individualização espiritual. Era o processo oferecido para tornar-se um indivíduo autônomo, autoconfiante responsável, nos termos que a Índia, como um todo necessitava naquele momento (BHAGAVAD GITA, 2005, p. 42).
\end{abstract}

Além disso, é possível notarmos a presença do karman também no âmbito das relações internacionais, assim observado na obra do Bhagavad Gita, "na esfera das relações internacionais, a lei do karman manifesta-se em termos de adequação do poder e da justiça. [...] Visto sob o aspecto da violação e da ação, o universo, como uma ordem ética inviolável. Nisso reside o significado específico da lei do karman" (HANSON; STERWART, apud FREIBERG, 1996, p. 49).

Como observado anteriormente, o conceito de autonomia está vinculado com a ideia de karman e dharma. No entanto, o mesmo também está associado com uma terceira concepção, nesse caso a ação, ou seja a autonomia na perspectiva indiana é construída e compreendida a partir desses três elementos.

Em relação a ação, a mesma pode ser motivada por três aspectos, a bondade; interesses próprios e egoístas; e questões ilusórias, sem ponderar danos e consequências. O indivíduo age com bondade, quando as atividades realizadas sem visar recompensas ou por serem motivadas pelo egoísmo. Em contrapartida, às ações que são fundamentadas pelos interesses próprios ou egoístas, são enquadradas na paixão. Por último, as ações que são feitas pelas questões ilusórias, sem refletir nas possíveis consequências e danos que essa conduta pode gerar, tanto para si quanto para os demais, esse tipo de ação integra o modo da ignorância. Vale ressaltar, que o conhecimento desenvolve um papel importante na vida do ser humana, como é destacado na obra, "o Senhor onipotente não assume nem a má nem a boa ação de ninguém. Mas a ausência de conhecimento, que recobre o conhecimento, é por ela que os homens se desorientam" (BHAGAVAD GITA, 2005, p. 15).

As três formas de agir, o primeiro é o não agir trata-se da inatividade e omissão, é um agir perverso e negativo, uma vez que está ligado com a ociosidade; o falso agir é o negativo que agride tanto os outros seres humanos quanto a própria natureza; o reto agir não é de fácil distinção, pois é a observância de todos os 
mandamentos e leis, da liberdade, do respeito, da responsabilidade do amor, e um dos princípios mais importantes, é o desapego (BHAGAVAD GITA, 2005, p. 17).

No que diz respeito aos agentes, o Bhagavad Gita retrata três tipos, o primeiro corresponde ao ser bom, são as pessoas que possuem bom ânimo, não são individualistas e conseguem proteger a si mesmo da influência de acontecimentos bons ou ruins. 0 segundo tipo de agente é denominado como apaixonado, são os seres humanos violentos, impacientes, sempre visam receber recompensas pela suas práticas e são abalados pelas adversidades da vida. O agente denominado ignorante, são os indivíduos indisciplinados, teimosos, maliciosos, preguiçosos e procrastinadores.

O intelecto é também analisado a partir do vínculo que os seres humanos possuem com as questões materiais, nesse sentido a pessoa que está situada na bondade não consegue diferenciar de forma precisa as dualidades da ação. Em contrapartida, o intelecto que está no modo da paixão, o indivíduo é incapaz de gerar a percepção do que se enquadra com o reto agir (dharma) e a ação não condizente com o dever (adharma), além disso as ações corretas e erradas são mescladas, impedindo uma interpretação clara. Por último, temos o modo da ignorância, no momento em que o ser humano não leva em consideração as injustiças (adharma) e transforma as mesmas como se fossem justiças (dharma).

Vale ressaltar que os três modos estão em uma constante disputa, pois muitas vezes uma tem maior destaque em comparação às demais, como é citado no Gita "às vezes o modo da bondade se torna proeminente, derrotando os modos da paixão e da ignorância, ó filho de Bharata. Às vezes, o modo da paixão sobrepuja a bondade e a ignorância, e outras vezes a ignorância derrota a bondade e a paixão" (PRABHUPADA, 1985, p. 686). Apesar disso, Gita mostra que o indivíduo quando está no modo da bondade seguirá um caminho da felicidade, no modo da paixão resultará em ações frutíferas, e o modo da ignorância quando extingue o conhecimento faz com o indivíduo siga para o estado da loucura.

Segundo o diálogo entre Krishna e Arjuna, há destaque na dualidade entre a noção de ignorância e conhecimento, pois os indivíduos situados neste modo estão na escuridão, ou seja, perdidos e iludidos, fazendo com que os frutos colhidos sejam negativos. Em contrapartida, o conhecimento que Krishna apresenta é ligado ao transcendental, que todos os seres humanos devem buscar constantemente, porque o mesmo é responsável por fazer a aproximação dos seres humanos com o divino. 
Volto a lhe expor esta sabedoria suprema, o melhor entre todos os conhecimentos, conhecendo o qual todos os sábios atingiram a perfeição suprema.

Fixando-se neste conhecimento, a pessoa pode alcançar uma natureza transcendental igual à Minha. Nesta situação, ela não nasce no momento da criação nem é perturbada no momento da dissolução. (PRABHUPADA, 1985, p. 679-680).

Em suma, no hinduísmo todos os indivíduos possuem o karman e o dharma reverberadas por suas ações, como notamos o caso do Arjuna, onde o mesmo sempre nasceria em cenários de guerras. Nesse sentido, as pessoas precisam desempenhar suas obrigações dentro da sociedade indiana, resultando na organização de acordo com o sistema de castas, ou seja, o fator que determina a posição social de cada ser humano é advinda da ação.

\begin{abstract}
Estas quatro ordens sociais universais da sociedade humana são descritas pelo Senhor Krishna relacionando a natureza pessoal de cada um, qualidades, trabalhos, e não o seu nascimento. Aqueles que estão dominados pelo modo de bondade e são pacíficos, e autocontrolados, são chamados de Brãhmanas. Aqueles que são controlados pela paixão e preferem engajar-se na administração e serviços de proteção são classificados como Ksãtriyas. Aqueles sobre os modos mistos de paixão e de ignorância e que engajam-se na agricultura e no comércio, são chamados de Vaiyas. Aquela maioria, que se encontra no modo inferior ou da ignorância, são chamados de Sudras, e suas naturezas são de servir a outras três ordens sociais (BHAGAVAD GITA, 2005, p. 323).
\end{abstract}

\title{
4.1.3 Ação política autônoma no Bhagavad Gita
}

De um ponto de vista epistemológico, a revelação de Krishna feita à Arjuna indica a limitação da compreensão humana ante a manifestação fenomênica das coisas e circunstâncias. Essa limitação, apesar de superável, é capaz de provocar a sensação de desânimo no herói e a concepção de uma ação incorreta - que no caso de Arjuna, trata-se de sua falta como xátria cujo dever é lutar por uma causa justa - decorre do fato do príncipe estar sendo dominado por uma ilusão, assediado por "aquilo que é demasiado humano" (manushya). É como se Arjuna estivesse vendo incorretamente a realidade, ou apenas uma parte dela, apreciando-a excessivamente pela sua dimensão material (FEUERSTEIN, 2015, p. 95-97). Para libertar Arjuna de seus padrões mentais e ajudá-lo a cumprir o seu dever de príncipe guerreiro (purusakara), Krishna apresentará os meios, um curso de ação. Para isso, introduz uma revelação que versará sobre a estrutura do universo, as modalidades do ser e as vias que cumpre seguir para obter a libertação final (ELIADE, 2011, p. 212).

Segundo Brodbeck e Black (2007, p. 6), os participantes da guerra e seus associados são ignorantes dessa dimensão maior, mesmo sendo influenciados por ela. Quer dizer que, 
em certo sentido, a ação política de cada um (purusakara) é condicionada pelos negócios dos deuses (daiva); por isso a revelação do daiva poderia ajudar Arjuna a pensar a melhor forma de proceder como príncipe. Note que, nesse caso, a ação política (purusakara) está mais ou menos condicionada a um maior ou menor entendimento de uma dimensão transcendente, onde opera a vontade e os negócios divinos. Numa síntese abrangente, a revelação informa Arjuna que aquilo que ele vê como "tio" e "primo" não deixará de ser, mesmo se mortos na guerra: "em verdade, nunca [houve um tempo que] eu não fui, [nem em que] tu não foste, [nem em que] estes chefes não foram, nem tampouco nenhum de nós deixará de ser doravante" (FEUERSTEIN, 2015, p. 97).

A mensagem é nítida. Ela aponta para a existência de uma realidade imutável (avyaya) que ninguém é capaz de destruir, um "Si Mesmo" que nunca nasceu nem jamais morrerá. Nesse sentido, o Gita é uma canção à imortalidade. Seus trechos procuram demonstrar ou lembrar aos homens e mulheres que a manifestação material da existência é um aspecto transitório, mutável, não primordial e, portanto, ilusório. A dimensão material é a consequência de uma realidade mais essencial, eterna, perene, primordial, que não morre quando morre o corpo. O corpo, aliás, na revelação de Krishna não passa de "vestes usadas" assim como um homem, lançando fora as vestes usadas, toma outras novas, assim também o [Si Mesmo] incorporado, lançando fora os corpos usados, entra em outros [corpos] novos" (FEUERSTEIN, 2015, p. 99).

O esforço de Krishna é mostrar a Arjuna que aquilo que ele vê não está de acordo com a realidade primordial do universo, o plano transcendente da existência (daiva). Assim, para que possa cumprir seu dever como xátria, Arjuna precisaria se desfazer de uma ilusão provocada pelos sentidos imediatos, e isso começaria pelo estudo e compreensão da realidade dos deuses. Como perceptível, a categoria de ação política (purusakara) tem, no Gita, primordial relevância. A função da revelação é simplesmente auxiliar um líder político a conceber um curso de ação autônoma, defrontado que está por um vultoso problema de ordem moral, política e social.

No Gita, a categoria de ação política como autonomia tem um lugar central e uma expressão conceitual muito particular. De acordo com a narrativa e seus comentadores, a ação política autônoma (purusakara) é uma expressão do karman. O karman do ser humano, segundo Freiberger (1996, p. 47), é "o seu agir, a soma de seus hábitos, tendências, maneirismos e peculiaridades naturais, manifestados naquilo que ele faz". 
Portanto, karman é o ato concebido a partir do repositório de hábitos mentais, das tendências e peculiaridades de uma pessoa ou de um agrupamento de indivíduos. $\mathrm{Na}$ verdade, o karman é um conceito abrangente. Ele não indica apenas o ato em si, mas também os resíduos provocados pelo ato. Afinal, todo ato produz bons ou maus resultados que sobrevivem às pessoas. Por exemplo, até certo ponto, a ação de Arjuna (purusakara) está presa pelo karman enquanto resíduo, porque foi a astúcia e a inveja de tios e primos que provocaram seu exílio e, em última instância, a guerra. O karman aponta para a ideia de que a partir das escolhas de cada um, dos atos e das deliberações humanas, levanta-se um cenário complexo e imbricado de resíduos e efeitos, positivos e negativos, pessoais e impessoais.

Trata-se de um conceito penetrante: ao indicar que a ordem social e política não passa de uma rede de efeitos provenientes de escolhas humanas, a categoria da ação (purusakara) enquanto karman reproblematiza o conceito de ordem e transformação social (FREIBERGER, 1996, p. 47-48). De fato, nossas experiências, boas ou más, são, em boa medida, condicionadas pelos resíduos da ação alheia. Por exemplo: se o caixa do banco conserva má sua vontade e, com isso, provoca atrasos na fila, todos os indivíduos pagam o preço da má deliberação ou ação política autônoma de um indivíduo. Ou, se o governo delibera mal a estratégia econômica, e com isso provoca aumento dos preços de alimentos, toda a população sofre a consequência de uma deliberação desatenta, a ponto de ameaçar o orçamento do mês, sobretudo dos mais pobres.

Generalizando para as relações internacionais, a categoria de "ação política autônoma" (purusakara) enquanto karman ganha admirável poder explicativo. Em boa medida, os acontecimentos internacionais e a qualidade da ordem mundial são determinados pelos atos enquanto hábitos mentais, tendências, maneirismos e peculiaridades de pessoas e líderes políticos e suas respectivas consequências residuais. Quando Donald Trump decide proibir o ingresso de pessoas de sete países, majoritariamente muçulmanos, por considerá-los uma ameaça, o sofrimento e o constrangimento provocados aos estrangeiros não é o resíduo de uma deliberação, da ação política de alguém? (ADAMS, 2017). E, quando os homens e mulheres bomba acionam seus detonadores, em cenas dramáticas, provocando efeitos sociais, políticos e morais de indescritível sofrimento, não são esses sofrimentos e suas consequências físicas e morais o resíduo de uma deliberação, de uma escolha isolada que homens e mulheres bomba 
fizeram sobre a realidade? Sim, a verdade é que, em certa medida, somos reféns da nossa ação, que por sua vez responde a um hábito mental ou maneirismo nosso e dos efeitos da ação alheia, assim como Arjuna é refém, ao mesmo tempo, do seu desânimo causado pelos seus hábitos, tendências mentais e da inveja e astúcia de seus tios e primos que provocaram a guerra.

Em síntese: inerente a cada ato de Arjuna e demais personagens, quer desistam de combater ou não, pratiquem essa ou aquela obra, todos encontram o peso de sua consequência, pois ação e reação sempre estão polarizadas na própria vida (FREIBERGER, 1996, p. 47-48). Na aproximação ao Gita o que é inovador é poder pensar a autonomia decisória a partir de um conceito transcendente expresso pela ideia de imortalidade. Afinal, é a ideia de imortalidade que sustentará a mudança de postura mental de Arjuna, conduzindo-o bravamente a concepção de uma ação política legitimamente autônoma (purusakara). Na verdade, a revelação proposta por Krishna introduz na narrativa uma ideia reguladora que ajudará Arjuna a adequar dois princípios fundamentais: o poder (como capacidade de agir e controlar) e a justiça (enquanto senso de certo e errado; justo e injusto).

No Gita, a adequação ou o ajuste entre poder e justiça decorre necessariamente da identificação que se há de ter acerca de uma ideia reguladora maior, que no caso é a ideia da imortalidade da alma. Sem a ideia reguladora, é impossível conceber uma ação política, ter autonomia. Basta lembrar a paralisia de Arjuna no campo de batalha: "como agir?", pensa o príncipe angustiado, ou melhor, "como agir e controlar as circunstâncias com justiça?". Apesar da ideia de imortalidade ter uma conotação metafísica no Gita, seria possível interpretá-la como um postulado fundamental da categoria de "ação política autônoma" (purusakara).

Se a paralisia de Arjuna tem a ver com a compreensão imediata que ele faz da realidade imperfeita em que se encontra - tão imperfeita a ponto das circunstâncias obrigálo a lutar contra familiares - apenas a crença na imortalidade da alma poderia libertá-lo da aflição, fazendo-o agir. Pois, fica evidente que sua autonomia enquanto xátria está condicionada a necessidade que Arjuna tem de sentir que sua ação é justa. Desse modo, a ideia reguladora da imortalidade da alma convence Arjuna que ele estaria agindo bem, ou melhor, com justiça. É como se, do ponto de vista racional, a ideia reguladora da imortalidade estivesse propondo os seguintes termos: "não te aflija em lutar contra os 
familiares, Arjuna; pois eles agem mal; e mesmo que pereçam pelas tuas mãos, continuarão existindo e poderão melhorar-se como almas imortais num contínuo e infinito processo de aperfeiçoamento moral: lute Arjuna, lute!". Nesse caso, a ideia de imortalidade da alma passou a ser um requisito fundamental da ação política, pois foi baseado nela que Arjuna reconquistou sua autonomia decisória. Assim, essa ideia reguladora atuou para diminuir a tensão que havia entre poder e justiça, tornando-se a exigência moral, a crença da qual dependia todo o esforço de Arjuna para usar o seu poder como xátria.

Dentro desse cenário conceitual, seria possível interpretar o papel da ideia reguladora da imortalidade como metafísica imanente ou idealismo transcendental de estilo kantiano. Afinal, os fenômenos presenciados por Arjuna não passam de uma representação, um jogo de percepções, numa constante permuta entre dados mentais e habituais do protagonista, a guerra e a revelação de Krishna num todo unificado. Basta lembrar que para Kant "os fenômenos, sejam da experiência interna, sejam da experiência externa, não passam de representações, pois os dados da percepção nelas são transmutados, graças ao espaço e ao tempo, e não põem diante de nós um mundo de coisas em si [...] simplesmente, são condições dos fenômenos, doadoras de dados hiléticos, que o espaço e o tempo ordenam em fenômeno, isto é, numa representação unificada" (MORUJÃO, 2001 apud KANT, 2001, p. 20).

Afinal, quais são as correspondências mais exatas ou as aproximações que podem ser feitas entre o Gita e as Relações Internacionais? Por um lado, a verdade é que o Gita narra o drama de um líder político em usar a força, em exercer todo o seu poder como príncipe. Nas relações internacionais, o uso da força é um recurso que se abre como possibilidade, mas que deve ser usado como "última ratio", isto é, como último recurso baseado numa sólida "rationale". Os líderes precisam saber quando usar a força; e se as circunstâncias dizem que eles devem usar a força, mas hesitam ou fogem dessa responsabilidade, eles estão cometendo um "pamrih". Um líder comete um "pamrih" quando ele hesita ou recusa cumprir seu dever, sua responsabilidade com o Estado, com o seu povo por simpatia ou antipatia por amigos ou membros familiares. Por esse motivo para Sebastian e Lanti, "one episode in the epic of Bharatayudha where the God Wisnu advised Arjuna not to hesitate in going to war with their evil brothers, the Kurawa, is often used as a learning point" (ACHARYA; BUZAN: 2010, p. 154; 160). 
Dentro dessa compreensão, a visão do transcendente proposta por Krishna poderia ser interpretada como a "rationale" que justifica, dentro das circunstâncias em que Arjuna se encontra, o cumprimento do dever de xátria, evitando um "pamrih". Por outro lado, o estudo do Gita nas Relações Internacionais aponta uma ousada interpretação sobre a natureza da ordem internacional. Tem-se compreendido que no plano em que se movimentam os elementos de transformação da ordem internacional contemporânea, há forças pouco visíveis que exercem profundas influências; e uma delas, são as escolhas humanas. Diante dos dilemas políticos e sociais da atualidade, muito pouco se tem debatido sobre as formas conceituais que podem ajudar a compreender os fatores humanos, sejam eles imanentes ou transcendentes, capazes de definir cursos de ação justa e tomadas de decisão adequada sobre os mais variados aspectos, como direitos humanos, meio ambiente e segurança coletiva. Nesse sentido, o Gita pode indicar que na esfera das relações internacionais, a lei do karman não pode ser ignorada como um aspecto crucial a exercer pressão entre as noções de poder e justiça (HANSON; STEWART, 1985, p. 148). Se os movimentos de transformação da ordem internacional estão, em parte, associados aos móveis das ações políticas autônomas (elementos até aqui menosprezados especialmente pelas teorias sistêmicas, como a teoria de Kenneth Waltz) seria importante localizar ideias reguladoras capazes de atuar satisfatoriamente na tensa relação entre poder e justiça, entre força e ética. Ao inserir na disciplina novas maneiras de pensar, o Gita faculta conceber, na teoria e na prática, uma ação política autônoma diferenciada da matriz waltziana, plenamente justa e ética.

Neste seguimento, podemos compreender o conceito de ação política autônoma no Bhagavad Gita. A mesma é construída a partir da transcendência, oriunda da ideia de imortalidade, em razão da sua responsabilidade em regular o ajuste entre poder (força) e a justiça (definição de certo e errado). Deste modo, passa a influenciar no karman, gerando assim impactos na realidade material, porquanto, a mesma é construída a partir das consequências das tomadas de decisões individuais de cada ser humano, incluindo a resultância dos atos de outras pessoas. Por essa razão, Arjuna precisava lidar com seu próprio karman e com dos seus parentes, devido ao Dhritarâshtra não ter abdicado do trono, desencadeou a guerra entre os Karauvas e Pandavas.

Observamos assim, que os indivíduos desempenham um papel autônomo quando agem de acordo com o seu "eu" imortal, devido a eternidade da alma, ou seja, procedem 
independentemente do meio externo (mundo material). Podemos observar esse cenário, por meio da vivência de Arjuna, quando o recebe o conselho de Krishna, onde o príncipe deveria atuar de forma autônoma, no momento em que se desprende de seus sentimentos e apegos materiais, para se conectar com o plano transcendental.

À vista disso, Woods apresenta as três formas de autodeterminação traçadas no pensamento indiano, a primeira está associada a ideia que todos os acontecimentos são realizados pelo acaso (hatha), o segundo refere-se a noção que as ações dos indivíduos são influenciadas pelo destino (daiva), e a terceira autodeterminação está relacionada com o esforço dos seres humanos (purusakara).

Assim, Woods (1993) estabelece as duas formas de poderes existentes, o daiva e o purusakara. O primeiro, refere-se ao poder alcançado a partir da transcendência, isto é, concedido pelos deuses. Por outro lado, o segundo é o poder empreendido mediante ao empenho humano. Nesse caso, a ação política autônoma apresentada na obra do Gita, se conecta com o conceito de autonomia transcendental. Em outras palavras, uma autonomia a partir do esforço humano, mas sempre alicerçado no místico.

Desta forma, a ideia de autonomia transcendental expressa bem o que é mostrado no Gita, uma vez que a ação humana não pode ser desvinculada da ideia do místico, justamente porque os deuses comandam o tempo e o espaço, para todas as criaturas, tanto no plano terrestre quanto no espiritual. Um fator importante, é a renovação do tempo pelos deuses, feita através dos ciclos de morte e transcendência dos seres vivos. Nesse sentido os indivíduos não conseguem traçar seus destinos sozinhos:

[...] Como o próprio Krishna explica para Arjuna, que os seres humanos geralmente ignoram os papéis que são chamados a desempenhar no palco da vida. Isso leva à crença equivocada de que as únicas linhas que eles devem seguir são aquelas escritas por seus próprios desejos e inclinações. Na verdade, esses desejos e inclinações são cordas nas mãos do Mestre Supremo (WOODS, 1993, p. 92 tradução nossa).

O rei não deve agir somente com seu esforço pessoal, desconectando dessa forma do divino, pois passam a ter apegos e cobiças no plano terrestre "se desviando do seu papel designado, empregando suas energias espirituais para o acúmulo de riqueza material e para alcançar a supremacia na arte do armamento, ambos aparatos tradicionais do rei (ksatriya)" (WOODS, 1993, p. 91). Como veremos adiante, não é errado fazer o uso desses meios, mas a forma pelas quais são empregados. 
Ao analisarmos o conceito de autonomia política presente no Bhagavad Gita, e sua aproximação com o transcendental, é possível sintetizar o conceito de ação política autônoma, a partir do pensamento de Mahatma Gandhi, onde o mesmo afirma que o conceito está ligado com o domínio da formação da vontade, devido às emoções, afetos e percepções do líder político refletem diretamente com as tomadas de decisões do Estado, gerando impactos para a população, nas políticas públicas e na política externa do país (TURCI JÚNIOR, 2011).

Através do conceito de ação política autônoma, o hinduísmo possui uma perspectiva própria para interpretar o papel do Estado, no Gita (2005) o mesmo detém o uso da força. No entanto, fazer somente o uso mínimo é subjetivo, porém a violência só poderá ser aplicada para manter o dharma (ordem ou justiça), ou seja, a mesma não pode ser usada para resolver problemas ou mágoas pessoais.

O dever do ksatriya (rei) é proteger os cidadãos de toda classe de dificuldades, e por esta razão ele tem que aplicar a violência em casos apropriados para manter a lei e a ordem. Portanto, ele tem que conquistar os soldados dos reis inimigos, e assim, com os 'princípios religiosos', ele deve governar o mundo (BHAGAVAD GITA, 2005, p. 77).

Vale ressaltar, que fazer uso do poder bélico para dominar os demais países não pode ser considerado o melhor caminho, assim deverá ser analisado cada caso individualmente, pois é considerado kasar (método bruto). Outro fator a ser destacado, é o envolvimento na guerra, dado que não resulta em glória e por diversas vezes pode significar fraqueza, por parte do chefe de Estado. A melhor forma de deter poder, seria através de pressão ou halus (método civilizado) para aquisição da soberania (ANDERSON, 1990 apud SEBASTIAN; LANTI, 2010, p. 151).

Por fim, há o conceito de pamrih para explicar a queda do governante do poder, isso ocorre quando o líder político recusa ou hesita a cumprir um dever para com o Estado, devido a empatia ou simpatia por seus amigos ou familiares, além de exercer corrupção ou nepotismo. Isto posto, resulta no enfraquecimento do governante, derivando assim um novo cenário, pois haverá a mudança do representante do poder.

[...] O uso da força como parte da política oficial não pode ser descartado completamente. Mas tem que ser usado como último recurso, e tem que ser fundamentada em uma lógica sólida. Os líderes precisam saber quando usar a força. E se o situação determina que eles devem usá-lo, porém se eles hesitaram ou decidiram contra, então eles também estão tocando pamrih. Um episódio no épico de Mahabharata onde o deus Vishnu aconselhou Arjuna a não hesitar em ir à guerra contra seus parentes, os Kauravas, são frequentemente usados como um ponto de aprendizado (SEBASTIAN; LANTI, 2010, p. 160, tradução nossa). 
Em síntese, o Bhagavad Gita indica o caminho mais aconselhável para o ser humano seguir, no aspecto pessoal, no papel de cidadão e na esfera política. No âmbito do Estado, aplica-se o conceito de autonomia política, mas diferente das definições existentes desse conceito, no Gita apresenta sua conexão com o transcendental, pois há uma linha tênue entre o campo místico e terrestre. Para mais, a obra não se limita somente ao arcabouço teórico, porque há aplicabilidade prática do conceito na realidade presente. 


\subsection{O CONCEITO DE AUTONOMIA NA PERSPECTIVA OCIDENTAL}

Após a compreensão do conceito de autonomia política no Bhagavad Gita. A seção atual, apresentará como o conceito de autonomia política é compreendida no ocidente, tanto na concepção clássica, quanto na ressignificação do mesmo, através do pensamento de alguns autores da América Latina. Dessa forma, será possível a construção da análise comparativa do conceito de autonomia política na perspectiva no Bhagavad Gita, em relação a visão de autonomia ocidental.

\subsubsection{Autonomia política no Ocidente}

No ocidente, o conceito de autonomia política possui uma variedade de interpretações. Nessa continuidade, será necessário limitarmos a análise, para assim ser viável ter um entendimento do conceito clássico e sua manifestação nos estudos de Relações Internacionais. Nesse sentido, detemos atenção na perspectiva latino-americana, mais precisamente os autores nacionais, como Amado Cervo e Sombra Saraiva.

Assim, "para que se possa pensar o conceito de autonomia do ponto de vista espaçotemporal, é preciso situá-lo como produto da Modernidade no Ocidente, a qual remonta ao século XVI" (MUÑOZ, 2019, p. 89). Além disso, Muñoz (2019) destaca como o conceito clássico de autonomia é limitado apenas ao Estado. Consequentemente, o conceito cooperou para delinear as tomadas de decisões dos Estado, tanto na sua política externa quanto no âmbito interno, pois seria um caminho para o mesmo alcançar plenamente a ação política autônoma.

O conceito clássico de autonomia aproxima-se com a concepção de Estado Moderno de Max Weber. Para o autor, o Estado Moderno foi instrumentalizado a partir do estado racional, uma vez que somente o Estado detém o uso legítimo da força, justamente por ser soberano. Por essa razão, o Estado precisa lidar com diversas conjunturas, resultando na necessidade da utilização da racionalidade e burocracia, para conseguir o absoluto funcionamento (Weber, 1999).

De acordo com Saraiva, autonomia é um dos conceitos fundamentais nos estudos de Relações Internacionais, uma vez que o mesmo determina o comportamento dos tomadores de decisões globais. À vista disso, "a ideia e a prática da autonomia decisória ou 
simplesmente autonomia permeia a história da formação dos Estados modernos. Autonomia é o elo interno do Estado em sua inflexão para a conformação do sistema internacional. [É pensar] a experiência histórica da inserção dos Estados" (SARAIVA, 2014, p. 9 apud MUÑOZ, 2019, p. 82).

Como é exposto em Muñoz (2019), Cervo expressa que após a II Guerra Mundial havia muita discussão acerca das relações internacionais, principalmente entre os cientistas políticos e os historiadores, devido às discordâncias e as metodologias que eram empregadas. Isto posto, Cervo defende que as teorias e conceitos abordados nos estudos de relações internacionais, deveriam ser construídos sob a realidade que cada país está inserido. Pois, esses conceitos são construídos perante o olhar do países desenvolvidos, resultando na inviabilidade da aplicação dos mesmos nos países subdesenvolvidos e emergentes.

Em virtude disso, Cervo traça características para trazer uma definição precisa em relação aos conceitos. Dessa maneira, o autor apresenta que os conceitos são construídos por diferentes grupos acadêmicos, logo os mesmos irão retratar apenas a realidade daquele grupo. Outro ponto importante, é que os conceitos são criados em diferentes momentos, por isso cada um deles irá ter sua própria definição, porém intrinsecamente vão remeter àquele determinado tempo pelo qual foram projetados. Outra característica, demonstra que os conceitos são favoráveis para o debate, justamente porque cada um deles terá suas convicções, auxiliando nos debates e nas ações políticas. E por fim, todos os conceitos passam por diversos estudos empíricos, por essa razão os mesmos podem ser considerados como verdade absoluta (CERVO, 2008 apud MUÑOZ, 2019, p. 19).

Em suma, Muñoz (2019) aponta que o Ocidente conseguiu concretizar o conceito de autonomia política, cooperando dessa forma para o debate acerca dos estudos de relações internacionais. Uma vez que, esse conceito é fundamental na construção da política do Estado, pois o mesmo colabora na definição da ação política, tanto na esfera interna e quanto na política externa. Assim, passa a ser fundamental a construção e a consolidação desse conceito para o desenvolvimento da cátedra das Relações Internacionais.

\subsubsection{Autonomia Ocidental versus autonomia no Bhagavad Gita}


Após a explanação do conceito clássico de autonomia política para Amado Cervo e Sombra Saraiva, é fundamental trazermos para esse item a crítica do Luciano Muñoz, em torno da construção do conceito clássico ocidental. Para posteriormente ser viável a elaboração da análise comparativa mais precisa do contraste conceitual, do ponto de vista ocidental e oriental.

Para Muñoz (2019), Saraiva configurou o conceito de autonomia em algo sólido e contínuo, assimilando com uma flecha, onde o conceito sempre tende a seguir uma reta. Porém, o mesmo ocasionalmente tende a se desviar, no entanto podem ser definidos como movimentos normais, pois o conceito é considerado atemporal e fixo, a ideia deste conceito sempre estaria hábil a explicar as dinâmicas dos Estados. Dessa maneira, Muñoz (2019) crítica essa concepção de Saraiva, porque para o autor o conceito de autonomia não pode ter significado rígido e impenetrável, uma vez que há necessidade de ter abertura para modificações.

No que diz respeito à definição do conceito de autonomia apresentada por Cervo, Muñoz (2019), concorda com a ideia da elaboração de que cada conceito descreve um espaço-temporal próprio, e representa a percepção do grupo responsável pela sua idealização. Em contrapartida, Muñoz discorda das outras duas afirmações do autor, ligadas a ideia que os conceitos são carregados de significados positivos, e por isso exercem influências nas ações dos tomadores de decisões, mas Munõz contesta essa afirmação, uma vez que os conceitos não são criados, para desempenhar essa função. E por fim, Munõz (2019), descarta a afirmação de Cervo, quanto a verdade incontestável dos conceitos, devido os mesmos serem construídos a partir de estudos científicos, pois a academia busca desconstruir essas verdades absolutas, além de permitir aberturas para diversos debates.

Portanto, Muñoz (2019) aponta importância da flexibilização que o conceito de autonomia precisa ter, ou seja, há necessidade do aporte teórico de todos os autores, para o crescimento e enriquecimento da cátedra. Além disso, o autor cita que não é possível projetar somente uma significação do conceito de autonomia, como absoluto e inquestionável, pois ao analisar cada realidade deve ser empregada a definição conceitual mais pertinente, dado que "os conceitos devem ser compreendidos como ferramentas distintas para resolver problemas distintos. Não há, portanto, um quebra-cabeça único cuja solução pretendemos desvendar" (RORTY, 1989 apud MUÑOZ, 2019, p. 20). 
Nesse sentido, estamos de acordo com a perspectiva de Muñoz, mas a ausência da concepção oriental ainda permanece. Logo, segundo Acharya (2011), o pensamento das Relações Internacionais foi construído a partir da perspectiva ocidental, mais precisamente europeia e norte-americana. Desse modo, resultando em um debate insuficiente, já que excluíram as visões e realidades dos países orientais. Porém, o autor destaca que a cátedra não pode descartar as abordagens ocidentais, mas precisam incluir a perspectiva oriental nesse debate, pois cada uma traz contribuições pertinentes, abrindo espaço para existência das Relações Internacionais global.

Dessa forma, podemos notar que o autor Hans Morgenthau com a sua obra, a política entre as nações: a luta pelo poder e pela paz, possui grande influência na teoria realista, e consequentemente para os estudos de Relações Internacionais. Assim, a obra do Bhagavad Gita deveria ter a mesma visibilidade, uma vez que ambos possuem similaridades, e as diferenças presentes no Gita poderia acrescentar o debate dos estudos de relações internacionais.

O realismo clássico interpreta a natureza humana como um constante conflito pela defesa de sua integridade física e uma incessante busca pelo poder, sendo os fatores que movem o indivíduo, o amor, a esperança e o medo. (MORGENTHAU, 2003, p. 4-6). De fato, essa visão também é relatada no Bhagavad Gita, em virtude da mente dos indivíduos serem influenciadas pelo apego e aos desejos humanos. Todavia, os únicos desprendidos são os denominados como "um sábio de mente estável" (PRABHUPADA, 1985, p. 166).

Assim, Krishna entende que os seres humanos são presos e influenciados pelas suas emoções, porém como Arjuna era um príncipe, era inviável suas decisões serem tomadas a partir das emoções e medos, pois isso prejudicaria a imagem pública e seu propósito na Terra. Hans Morgenthau, aborda essa questão em sua obra, onde a razão tem que ser separada da emoção, ou seja, para atingir um cenário equilibrado, os indivíduos precisam ser objetivos e racionais.

Morgenthau (2003) expõe que o interesse é a base política, entretanto não somente dela, mas faz parte da lei da natureza. A noção de interesse está em todas as religiões, culturas e indivíduos, assim notamos que o interesse é universal o que muda são os tipos/ conteúdos dos interesses. Nesse aspecto, entendemos o motivo da guerra entre os Karauvas e Pandavas, pois o Dhritarâshtra estava sendo impulsionado pelo seu interesse constante pela busca de poder. 
O conceito de alta justificativa presente na perspectiva de Morgenthau (2003), possui similaridade com a história do Dhritarâshtra, relatado no Gita. Pelo fato do mesmo ter conhecimento que não poderia herdar o trono, apesar de ser o próximo da linha de sucessão, devido à sua incapacidade visual. Porém, esse fato não o impediu de assumir o trono, ignorando a tradição, sobrepondo a sua própria vontade diante ao que era estabelecido na época, gerando um cenário de guerra. Posto isso, os líderes políticos acreditam sempre estarem respaldados, supondo que suas atitudes são válidas.

Apesar do realismo entender que a aplicação do poder bélico serve apenas para mostrar o poder, contudo realizar uma guerra deveria ser considerado como o último meio. No caso de Arjuna, Krishna mostra que "considerando seu dever específico de ksatriya (rei), você deve saber que não há melhor ocupação para você do que lutar conforme determinam os princípios religiosos; e assim não há necessidade de hesitação" (PRABHUPADA, 1985, p. 139). Com isso, percebemos a indispensabilidade da participação de Arjuna na guerra, pois a reputação de príncipe estava em risco, por causa da ameaça constante por parte da família. Além disso, no realismo as medidas traçadas para preservar o equilíbrio de poder, são inevitáveis, porque é somente através desses mecanismos que o sistema internacional poderia estabilizar-se.

O realismo clássico mostra que a autonomia e a soberania dependem do equilíbrio de poder, pois se o cenário permanece estável a autonomia do Estado continuaria a existir (MORGENTHAU, 2003). Com isso, percebemos que se não fosse a guerra, Arjuna poderia ser prejudicado, tanto em sua ocupação política quanto em suas tomadas de decisões, colocando também a vida da população em risco pela guerra. Tendo como resultado a credibilidade e a fragilidade da imagem do príncipe, diante da população.

Apesar da teoria realista ter aproximação com do Bhagavad Gita, há uma diferença fundamental, como podemos notar no jogo de soma zero, para os realistas como o sistema internacional é anárquico, quando ocorre uma disputa entre Estados, sempre um Estado teria ganhos positivos, já o segundo teria resultados negativos. Todavia, no Bhagavad Gita o resultado da guerra, geraria um outro desfecho, por mais que os familiares de Arjuna falecessem em campo de batalha, os mesmos teria uma oportunidade de evoluírem e crescerem como seres humanos, nas próximas reencarnações. Segundo Krishna, na vida terrena os parentes e amigos de Arjuna estavam repletos de impurezas e ambições ruins, à 
vista disso, a morte não seria um resultado de perdas, mas de ganhos que iriam ter no plano espiritual.

\begin{abstract}
Neste mundo, não há nada tão sublime e puro como o conhecimento transcendental. Este conhecimento é o fruto maduro de todo misticismo. E aquele que se familiarizou com a prática do serviço devocional desfruta deste conhecimento dentro de si no devido tempo.

Um homem fiel que se dedica ao conhecimento transcendental e que subjuga seus sentidos está qualificado a obter tal conhecimento, e, tendo-o alcançado, ele atinge rapidamente a paz espiritual suprema (PRABHUPADA, 1985, p. 284).
\end{abstract}

Deste modo, a autonomia apresentada no Bhagavad Gita poderia ser entendida como uma autonomia transcendental, justamente por causa das reflexões e ensinamentos serem expressas em um contexto que ultrapassa o entendimento terreno, pois além do fato dos conselhos serem provenientes da figura do deus Krishna, existe uma continuidade da consciência e até mesmo a oportunidade de um processo evolutivo do ser humano, que está presente no místico. 


\section{CONSIDERAÇÕES FINAIS}

A partir da pesquisa realizada foi possível alcançar os objetivos e confirmar a hipótese, em relação a contribuição do Bhagavad Gita, para o campo teórico das Relações Internacionais. Além disso, cooperou em uma parcela para reflexão do ocultamento das realidades que não são provenientes da construção ocidental e para diversificação do debate teórico da cátedra de Relações Internacionais, uma vez que a mesma foi elaborada sob a visão de mundo ocidental.

À vista disso, a primeira seção buscou contextualizar sobre a narrativa do Bhagavad Gita, para ser possível o entendimento do pensamento indiano. A partir disso, investigar a construção conceitual da ação política autônoma, uma vez que o mesmo está plenamente conectado com a noção do místico. Assim, definir o conceito como autonomia transcendental, é viável, devido às ações praticadas ultrapassarem o plano terrestre, ou seja, é fundamental agir também com consciência espiritual.

Dessa forma, na segunda seção foi essencial a elaboração da análise comparativa entre o entendimento do pensamento ocidental em contraste ao oriental. Sendo assim, o pensamento clássico ocidental, representado por Amado Cervo e Sombra Saraiva, tende associar o conceito de autonomia como algo sólido e inflexível, porém seguindo as críticas de Luciano Muñoz notamos a insuficiência conceitual, para uma análise mais robusta, da política mundial. Entretanto, apesar da tentativa da diversificação e inclusão do debate teórico, ainda não foi suficiente para inserção do pensamento oriental.

Em suma, a presente pesquisa buscou introduzir o Bhagavad Gita, como uma fonte teórica para o campo de estudos das Relações Internacionais, propondo como alternativa à contemplação de diversas produções textuais não-ocidentais, para ser possível o enriquecimento da cátedra. Portanto, essa pesquisa fica como uma amostra e incentivo, para os demais pesquisadores, na contribuição para expansão teórica das Relações Internacionais, em escala global. 


\section{REFERÊNCIAS}

ACHARYA, Amitav. Dialogue and discovery: in search of International Relations Theories beyond the west. Millennium: Journal of International Studies, United Kingdom, v. 39, n. 3, p. 619 - 637, out. 2011.

ADAMS, Gordon. Accelerated change. Trump and the new global system. The Washington Spectator. Mar. 9, 2017. Disponível em: https://washingtonspectator.org/acceleratedchange-adams/. Acesso em: 12 de abril de 2020.

BARKAWI, Tarak; LAFFEY, Mark. The postcolonial moment in security studies. Review of International Studies, v. 32 n. 2, 2006.

BRODBECK, Simon; BLACK, Brian. Gender and narrative in the Mahabharata. London: Routledge, 2007.

ELIADE, Mircea. História das crenças e das ideias religiosas: de Gautama Buda ao triunfo do cristianismo. Trad. Roberto Cortes de Lacerda. Rio de Janeiro: Zahar, 2011.

FEUERSTEIN, George. Bhagavad-Gita: uma nova tradução. Trad. de Marcelo Brandão Cipolla. São Paulo: Pensamento, 2015.

FREIBERGER, Mário J. Ação e tempo na Bhagavad- Gita. Porto Alegre: EDIPUCRS, 1996.

HANSON, Virginia; STEWART, Rosemarie. Karma: a lei universal da harmonia. São Paulo: Pensamento, 1985.

LORENZ, Francisco Valdomiro. Bhagavad-Gita: a mensagem do mestre. São Paulo: Pensamento, 2006.

MORGENTHAU, Hans. A política entre as nações: a luta pelo poder e pela paz. Trad. Oswaldo Biato. Brasília e São Paulo: Universidade de Brasília, Instituto de Pesquisa de Relações Internacionais e Imprensa Oficial do Estado de São Paulo, 2003.

MORUJÃO, Alexandre Fradique. Introdução. In: KANT, Immanuel. Crítica da razão pura. Trad. Manuela Pinto dos Santos e Alexandre Fradique Morujão. Lisboa: Fundação Calouste Gulbenkian, 2001. p. 5-26

MUÑOZ, Luciano da Rosa. Intelectuais, militares e diplomatas: uma genealogia da autonomia no Brasil (1946-1974). 2019. 433 f. Tese (Doutorado em Relações Internacionais) - Instituto de Relações Internacionais, Universidade de Brasília, Brasília. 2019.

PRABHUPADA, A.C. Bhaktivedanta Swami. O Bhagavad-Gita: como ele é. Trad. Marcio Lima Pereira Pombo. São Paulo: Fundação Bhaktivedanta, 1985. 
PRASÃD, Rãmãnanda. O Bhagavad Gita: A canção de Deus. Trad. Sri Swãmi

Krsnapryãnanda Saraswãti. 2. ed. Porto Alegre: Sociedade Internacional do Gita do Brasil, 2005.

SEBASTIAN, Leonard C; LANTI, Irman G. Perceiving Indonesian approaches to international theory. In: ACHARYA, Amitav; BUZAN, Barry. Non-western international relations theory: perspectives on and beyond Asia. London: Routledge, 2010. p. 148-173

TURCI JÚNIOR, José Rubens. Uma visão polifônica sobre a gênese da ciência do sagrado no Bhagavad Gita. Revista de estudos e pesquisa da religião, Juiz de Fora, v. 14, n. 2, p. 247260, set. 2011.

WEBER, Max. 1999. Economia e sociedade: fundamentos da sociologia compreensiva. Brasília: UnB. v. 2.

WOODS, Julian F. Destiny and human initiative in the Mahabharata. Albany: State University of New York, 1993. 